\title{
Muuttuva julkinen hallinto ja työelämäkompetenssien suuntaviivat suomalaisessa korkeakoulutuksessa
}

\author{
Jari Autioniemi, Niina Mäntylä, Jonna Kosonen, Hanna Partinen \& \\ Hanna-Kaisa Pernaa
}

\section{ABSTRACT \\ Changing public administration and guidelines for working life competencies in Finnish higher education}

What are the requirements of working life in the public administration in the future? What working life skills should be emphasized in national education of Public Administration? The results of the article base upon four empirical research materials: (1) a study based on anticipatory material, (2) a survey, (3) a workshop, and (4) an expert panel on working life requirements in public administration. The findings are analysed and construed with reference to international and national literature. The results emphasize change, transformation ability, networking public administration, phenomenon-based orientation, collaboration and customer orientation.

Keywords: public administration education, competencies, working life skills, development

\section{TAUSTA JA TUTKIMUSKYSYMYKSET}

Tässä artikkelissa tarkastelemme julkisen hallinnon tehtävissä edellytettäviä työelämävalmiuksia koulutuksen kehittämisen näkökulmasta. Yhteiskuntatieteellisen korkeakoulutuksen arviointiraportin mukaan ennakoivaa tietopohjaa työelämän tarpeista ja toimintaympäristön muutoksista saadaan yliopistoissa tällä hetkellä etenkin uraseurantojen ja erilaisten palautteiden kautta. Sidosryhmien edustajat kuitenkin kokivat, että yliopistot eivät ole olleet kovin hyviä työelämämuutosten ja osaamistarpeiden ennakoinnissa (Seppälä ym. 2020, 51, 53). Myös jatkuvan oppimisen avulla on tarkoitus vastata akuutteihin koulutustarpeisiin. Toisaalta näyttää siltä, että erityisesti jatkuvan oppimisen osalta yliopistoilla on haasteita soveltaa asiantuntijuuttaan työelämän tarpeisiin $(2020,81)$.

Syynä edellä mainittuihin haasteisiin on ainakin osittain se, että julkisen hallinnon toimintaympäristön muutokseen liittyen kompetenssien jäsentämistä ei ole juurikaan tehty, varsinkaan kotimaisessa tutkimuksessa. Kotimaisesta tutkimuksesta ei siis löydy vastausta kysymykseen, millaista työelämäosaamista julkisen hallinnon toimintaympäristön muutokset edellyttävät. Tässä on tutkimusaukko, sillä julkisen hallinnon toimintaympäristössä on tapahtunut viime aikoina merkittäviä muutoksia. Johtajat ja asiantuntijat työskentelevät jatkuvien uudistusten ja poliittisten paineiden aallokossa sekä aiempaa verkottuneemmassa, kansainvälisemmässä ja kompleksisemmassa ympäristössä. Lisäksi digitalisaatiolla on entistä merkittävämpi rooli hallinnollisessa toiminnassa (McQuiston \& Manoharan 2017). Digitalisaation taustalla puolestaan vaikuttaa tuottavuusdiskurssin ohella muitakin kompetenssitarkastelulle olennaisia periaatteita, kuten yhteistyön ja asiakaslähtöisyyden ideat (Parviainen ym. 2017, 14, 28).

Julkisen hallinnon kompetenssien tarkastelu näyttäytyy aiemmissa tutkimuksissa hyvin yleispiirteisenä. On tunnistettu, että kompetensseja analysoivassa tutkimuksessa ei ole myöskään keskitytty systemaattisesti julkisen hallinnon toimintaympäristön muutoksiin ja siitä johtuviin, muuttuviin kompetenssitarpeisiin (Kotiranta \& Ahonen 2017, 32). Nyholm ja Virtanen (2017) korostavat, että tällaista toimintaympäristön muutoksiin peilautuvaa kompetenssitutkimusta ei ole tehty juuri lainkaan. Havaitsimme myös, että niiltä osin kuin kotimaista tutkimusta on käytettävissä, on se selkeästi keskittynyt pelkästään johtamiskompetenssien analyysiin. Koulutuksen kehittämisessä ja sen tutkimuksessa puo- 
lestaan on tyypillisesti korostettu lähinnä geneerisiä taitoja, kuten ongelmanratkaisutaitoja sekä vuorovaikutus- ja kommunikaatiotaitoja (OPH 2019, 28-34).

Koska olemassa oleva hallinnon kompetenssitutkimus on yleispiirteistä, artikkelimme aiemman tutkimuksen muodostama kehys näyttää liikkuvan hyvin eri tasolla kuin kokoamamme empiirinen aineisto. Tässä artikkelissa fokuksemme on julkishallinnon spesifeissä kompetensseissa. Vastaamme edellä esitettyihin jäsentymättömyyden ja yleisyyden haasteisiin ensinnäkin jäsentämällä artikkelissa toimintaympäristön muutoksia neljän pääkategorian kautta. Empiirinen aineistomme peilaa yksityiskohtaisesti näistä johtuvia kompetenssitarpeita. Tutkimuksemme täyttää kotimaista tutkimusaukkoa systematisoimalla johtamiskompetenssien lisäksi muita osaamistarpeita. On selvää, että julkisen hallinnon toimintaympäristön muutos edellyttää tulevaisuuden osaamistarpeiden ja kompetenssien parempaa jäsentämistä ja huomioimista. Tarve on sekä koulutuksen järjestäjillä että julkishallinnon organisaatioilla. Artikkelimme tarjoaa tietoa näihin tarpeisiin, sillä pyrkimyksenä on vastata seuraaviin kysymyksiin: Mitkä ovat työelämän kompetenssitarpeet julkisen hallinnon muuttuvassa toimintaympäristössä? Mitä työelämävalmiuksia julkisen sektorin tehtäviin valmistavassa kansallisessa koulutuksessa tulisi korostaa? Peilaamme artikkelissamme empiirisen aineiston tuloksia kotimaisen diskurssin lisäksi laajempaan kansainväliseen jäsentelyyn julkishallinnon muutostrendeistä ja kompetensseista.

Artikkelimme tulokset perustuvat neljään empiiriseen tutkimusaineistoon: kirjallisen ennakointiaineiston perusteella tehtyyn selvitykseen; julkisen hallinnon toimijoille tehtyyn osaamistarvekyselyyn; julkisen hallinnon toimijoiden ja yliopiston vuorovaikutteisen työpajan tuloksiin sekä eDelphi-asiantuntijapaneeliin tulevaisuuden työelämän vaatimuksista julkishallinnossa.

Tarkoitamme artikkelissamme kompetenssilla korkeakoulutuksen avulla saavutettua, kokonaisvaltaista ja dynaamista yhdistelmää osaamista, tietoja, taitoja ja eettisiä arvoja, sekä kykyä käyttää niitä tarkoituksenmukaisesti erilaisissa julkisen hallinnon työtehtävissä. (Ks. Reichard \& van der Krogt 2014, 3; Lokhoff ym. 2010, 21.)
Tarkastelemme kompetensseja koulutuksen kehittämisen näkökulmasta: tarkoituksenamme ei ole kuitenkaan vastata kysymykseen, miten esille nousseet kompetenssitarpeet tulisi siirtää opintojaksojen osaamistavoitteiksi. Keskitymme artikkelissa siihen, millaisia valmiuksia julkisen hallinnon tehtäviin valmistavan koulutuksen tulisi tarjota.

Artikkelin aluksi tarkastelemme, mitä julkisen hallinnon kompetensseilla tarkoitetaan kirjallisuudessa. Tämän jälkeen arvioimme kompetensseja suhteessa julkisen hallinnon tehtäviin valmistavaan korkeakoulutukseen. Julkisen hallinnon kompetenssit, kompetenssit julkisen hallinnon tehtäviin valmistavassa korkeakoulutuksessa ja ydinkompetenssit kansainvälisessä ja kansallisessa tarkastelussa muodostavat lukuina artikkelin teoreettisen osuuden. Näitä lukuja seuraa artikkelin neljän empiirisen tutkimusaineiston läpikäyminen ja analyysi monitahoarvioinnin avulla. Päätämme artikkelin johtopäätöksillä ja keskustelulla. Käytämme artikkelissa käsitettä julkinen hallinto, joka sisältää alan koulutuksen, oppialan ja julkisen hallinnon toiminnan. Julkishallinnon käsitteellä viittaamme alan koulutukseen ja oppialaan.

\section{JULKISEN HALLINNON KOMPETENSSIT}

\section{Kompetenssitarpeet julkisen hallinnon tehtäviin valmistavassa korkeakoulutuksessa}

Suomessa julkisen hallinnon tehtäviin valmistavaa korkeakoulutusta annetaan monessa yliopistossa: joissain se on oma koulutusohjelmansa, toisissa osa muuta koulutusta. Julkishallintoon liittyvä koulutus on poikkitieteellistä ja se kattaa kysymyksiä valtio-opista, johtamisesta, oikeustieteestä, sosiologiasta ja filosofiasta (Ongaro 2019; Wright 1974). Suomessa merkittävä osa tämän alan koulutuksessa järjestetään hallintotieteellisissä koulutusohjelmissa. Julkishallinnon koulutus on näin osa myös yhteiskuntatieteellistä koulutusta, jota on arvioitu esimerkiksi Suomessa kansallisen koulutuksen arviointikeskuksen (KARVI) toimesta. Tuoreimmassa raportissa todetaan, että yhteiskuntatieteellisellä alalla sekä kandidaatti- että maisteriohjelmien työelämärelevanssi on hyvällä tasolla. Työnantajien toiveisiin vastaavat erityisesti opintojen laaja-alai- 
suus, sekä tutkintojen tarjoamat analyysi- ja ongelmanratkaisutaidot ja opiskelijoiden kriittisen ajattelun kehittäminen. Yhteiskuntatieteellisen alan tutkinnot omaavat korkean työelämärelevanssin niiden geneerisyyden vuoksi, mutta samanaikaisesti opiskelijat näkevät tässä myös ongelmia. Geneerisyys heikentää käytännönläheisyyttä, eikä työelämäosaaminen näyttäydy selkeänä opiskelijoiden suuntaan (Seppälä ym. 2020, 76).

Nykyään julkishallinnon koulutuksessa painotetaan uusia taitoja ja kompetensseja. Muutaman vuosikymmenen sisällä koulutuksen sisältö on muuttunut laajasti: esimerkiksi julkisella sektorilla toimivilta johtajilta odotetaan innovatiivisuutta eikä pelkkää "hallinnollista" käyttäytymistä, keskittymistä ihmisiin rakenteiden sijaan ja luottamuksen ensisijaisuutta kontrolliin nähden (Larat 2017). Myös tunneälyn merkitystä korostetaan (Berman \& West 2008).

On oletettavaa, että kompetenssit jatkavat muuttumistaan tulevien vuosikymmenten aikana. Tämä tarkoittaa työelämässä toimivien virkamiesten osaamisen täydentämistä. Oma aiheensa on, miten muutokset vaikuttavat opettajilta vaadittaviin kompetensseihin (Denhardt 2001, 529-530). Suomalaiset yhteiskuntatieteellisen korkeakoulutuksen tarjoajat ovat arvioineet, että koulutuksella vastataan tällä hetkellä moninaisiin modernin yhteiskunnan osaamistarpeisiin, joita ovat mm. digitalisaatio, kestävä kehitys, kansainvälistyminen ja muuttoliikkeestä aiheutuvat osaamistarpeet. Myös johtaminen ja yleiset asiantuntijatyöhön liittyvät valmiudet nousivat esille tarkoittaen esimerkiksi vaikeiden ja laajojen yhteiskunnallisten kysymysten analysointitaitoja ja kykyä haastaa vallitsevia käytäntöjä (Seppälä ym. 2020, 57).

\section{Ydinkompetenssit kansainvälisessä ja kotimaisessa tarkastelussa}

Julkinen hallinto edellyttää hyvin moninaisten kompetenssien hallintaa. Esimerkiksi ICMA (International City/Country Management Association) on yhdistys, jonka tavoitteena on paikallisen julkisen hallinnon parantaminen ammattitaitoisella johtamisella. Yhdistys (2015) luettelee johtamiselle 14 ydinaluetta, jotka ovat 1) henkilökohtainen ja professionaalinen integriteetti; 2) yhteisön kohtaaminen; 3) tasa-arvo ja inkluusio; 4) henkilöstön tehokkuus; 5) henkilökohtainen resilienssi ja kehittyminen; 6) strateginen johtajuus; 7) strateginen suunnittelu; 8) toimintapoliitikkojen (policy) järjestäminen ja toteuttaminen; 9) vapaaehtoistyö ja asukaspalvelut; 10) palveluntarjonta; 11) teknologinen osaaminen; 12) talousjohtaminen ja budjetointi; 13) henkilöstöhallinto ja työvoimaan sitoutuminen sekä 14) kommunikaatio ja informaation jakaminen.

EPPA (European Perspective for Public Administration) -projekti nostaa esiin julkishallinnon kehitystä ja muuttuvaa roolia eurooppalaisesta näkökulmasta. 2014-19 kestäneen projektin eurooppalaista julkishallintoa kartoittaneessa loppuraportissa Geert Bouckaert ja Werner Jann $(2020,30-32 ; 460-465)$ nostavat esiin tarpeen säännölliseen koulutuksen ja tutkimuksen arviointiin, sekä niiden kytkentää käytännön julkiseen toimintaan. Raportissa korostetaan myös tarvetta välttää käytänteiden ja koulutuksen soveltamisessa "one-size-fits-all" -ajattelua ja nostaa esiin erilaisten kulttuurien mukanaan tuomaa rikkautta. Eurooppalaisen julkishallinnon - ja sen tutkimuksen - tekee globaalisti tarkasteltuna erityiseksi sen etno-lingvistinen moninaisuus ja toisaalta Euroopan unionin jäsenmaiden yhtenäisen hallinnan tavoitteet. (Bouckaert \& Jann 2020, 31-32.)

EPPA-projektissa tehdyn kyselyn tulokset julkishallinnon opettajille korostavat myös julkishallinnon koulutuksen houkuttelevuutta lahjakkaiden opiskelijoiden saamiseksi tulevaisuudessa: toisaalta esimerkiksi Pohjoismaissa houkuttelevuus on jo valmiiksi korkealla tasolla, mitä edesauttaa se, että opiskelijat työllistyvät korkeisiin tehtäviin julkisessa hallinnossa (Bertels ym. 2020).

NASPAA (Network of Schools of Public Policy, Affairs and Administration) (2014) suosittelee julkishallinnon maisteriohjelman perustuvan viiteen ydinkompetenssiin, joita ovat: julkisen hallinnan johtaminen ja johtajuus; vaikuttaminen ja osallistuminen julkisessa päätöksenteossa (public policy); analysointi, syntetisointi, luova ajattelu, ongelmien ratkaisu ja päätösten tekeminen; julkisen palvelutuotannon artikulointi ja soveltaminen; kommunikointi ja yhteistyö kansalaisten ja työvoiman kanssa (NASPAA 2014, 7; Haupt ym. 2017).

On huomioitava, että NASPAA toimii pohjoisamerikkalaisessa viitekehyksessä, vaikka 
verkosto pitääkin toimintaansa globaalina: Euroopassa NASPAA:n ydinkompetensseja on kritisoitu esimerkiksi tutkimusnäkökulman (Reichard \& van der Krogt 2014, 6) puuttumisesta. Toisaalta tieteellisen kompetenssin merkityksestä ei ole kansainvälisesti laajaa konsensusta (ks. esim. NASPAA 2014; ICMA 2015). Euroopassa ei kuitenkaan ole olemassa yhtä mallia julkishallinnon opettamiseen, ja koulutusta voidaan pitää moninaisena (Brans \& Coenen 2016). Esimerkiksi Keski-Euroopassa opetus perustuu käsitykseen julkishallinnosta taloustieteen ja johtamisen ilmiönä, kun taas Pohjois-Euroopassa opetukseen vaikuttavat laajemmin valtio-opilliset ja organisaatioteoreettiset lähestymistavat (Bouckaert \& Jann 2020, 23-24).

Eurooppalaisen julkishallinnon korkeakoulutettujen ydinkompetensseja luotaava Tuning-PAhanke perustuu laatuun ja akkreditointiin fokusoivan EAPAA (European Association for Public Administration), julkishallinnon tieteenalan eurooppalaisen ryhmittymän EGPA (European Group for Public Administration), sekä julkishallinnon koulutusta tarjoavien instituutioiden verkoston NISPAcee:n (The Network of Institutes and Schools of Public Administration in Central and Eastern Europe) vuonna 2013 käynnistyneeseen yhteiseen tutkimusaloitteeseen. Hanketta koordinoivat Theo van der Krogt ja Cristoph Reichard, jotka ehdottavat projektin aloittavassa raportissaan (2014) eurooppalaisen julkishallinnon ydinkompetenssien tarkentamista - NASPAA:n kompetensseihin pohjautuen - geneerisiin ja yksityiskohtaisempiin kompetensseihin, sekä laajentamista ottaen huomioon edellä mainitun tutkimusnäkökulman ja eurooppalaisen julkishallinnon koulutusrakenteen. Perustuen 21 maata ja 35 yliopistoa kattavaan kyselyyn, sekä yhdeksän EAPAAn akkreditoiman opinto-ohjelman tarkasteluun, van der Krogt ja Reichard jaottelevat kompetenssien tarkastelun seuraaviin yleisempiin kokonaisuuksiin:

1. johtaminen julkisessa hallinnassa;

2. osallistuminen ja myötävaikuttaminen julkiseen päätöksentekoon ja hallinnollisiin prosesseihin;

3. julkisen palveluperspektiivin artikuloiminen ja soveltaminen;

4. tuottava kommunikointi ja vuorovaikutus julkisessa sfäärissä;
5. julkiseen hallintoon liittyvien haasteiden analysointi ja ratkaiseminen tarkoituksenmukaisten tieteellisten menetelmien avulla sekä

6. julkisen toiminnan ja sen taustalla olevien tekijöiden ymmärtäminen.

Myös kansallisesti on tarkastelu erilaisia julkiseen hallintoon liittyviä kompetensseja. Pietiläinen tarkastelee (2010) väitöskirjatutkimuksessaan johtajien ammatillisten kompetenssien profiloitumista kompleksisessa ympäristössä. Pietiläinen erottelee seuraavia yksityiskohtaisia kompetenssitekijöitä: kansainväliset kompetenssit, kehittämis- ja ihmissuhdekompetenssit, pedagogiset kompetenssit, itsensä johtamisen kompetenssit, tieto- ja viestintätekniset kompetenssit, talous- ja strategiakompetenssit, verkostokompetenssit, palkkaus- ja työsuhdekompetenssit, projektikompetenssit sekä vieraiden kielten kompetenssit (2010, 133-135). Näiden kompetenssien pohjalta Pietiläinen tunnistaa viisi erilaista johtajaprofiilia (2010, 136-149). Tutkimuksen mukaan johtamistodellisuutta määrittävät ympäristön nopeat muutokset sekä ennalta-arvaamattomuudesta ja organisaatioiden yhteiskuntaan suuntautuvasta avautumisesta seuraava kompleksisuus. Kompleksisuuden näkökulmasta Pietiläinen (2010, 149-166) jaottelee kompetensseille viisi viitekehystä: yksilön henkilökohtaiset ominaisuudet ja identiteetti, systeeminen sisäinen ja ulkoinen vuorovaikutus ja tasapaino sekä systeeminen sisäinen ja ulkoinen vuorovaikutus ja muutos.

Luoman ym. (2020) mukaan organisaation johtaminen ilmiöiden ja toimintaympäristön kompleksisuuden kasvaessa edellytetään johtamisen tarkastelua "dynaamisena ja vuorovaikutteisena sekä yhteisöllisenä toimintana" (2020, 171). Johtamisen keskeisenä tehtävänä on tällöin erilaisten - yksilöjen, organisaatioiden ja niiden ympäristöjen asettamien - tavoitteiden yhteensovittaminen.

Kun johtamista tarkastellaan kompleksisen toimintaympäristön asettamien vaatimusten näkökulmasta, on syytä mainita tapaustutkimus, jossa tarkasteltiin opetus- ja kulttuuriministeriön alaisuudessa toimivan Opetushallituksen tietoista kehittämistyötä näihin haasteisiin vastaamisessa (Raisio ym. 2020). Yksi kehittämistyön lähtökohdista oli johtajuuden kehittämi- 
nen vuorovaikutusta ja yhteistyötä korostaen, sekä hierarkioita ja muodollishallintoa madaltaen $(2020,117)$. Tutkijat nimeävät kompleksisuusjohtajuuden tavoitteeksi adaptiivisen tilan luomisen mahdollistavan johtajuuden avulla. Kompleksisuusjohtajuusteorian mukaan mahdollistavan johtajuuden (enabling leaderhip) ymmärretään sijoittuvan organisaation toiminnassa operatiivisen johtajuuden (operational leadership) ja aloitteellisen johtajuuden (enterpreneurial leadership) väliin, luoden kytköksen organisaation virallisten rakenteiden ja sen sisäsyntyisen, epämuodollisen toiminnan välille. Muuntautumiskyvykkyys nimetään johtajille oleelliseksi ominaisuudeksi kaikissa näissä rooleissa toimimiselle tilanteen vaatimalla tavalla (2020, 111-112).

Kotiranta ja Ahonen (2017) ovat tutkineet, miten ylimpien virkamiesten kompetenssit ja johtajuus ovat muotoutuneet suhteessa toimintaympäristön muutoksiin. Kirjallisuuskatsauksen perusteella tutkijat korostavat, että ylimpien virkamiesten kompetenssitarpeista piirtyy epäyhtenäinen kuva sekä yleensä että johtajuuden alalla $(2017,2)$. Keskeiseksi kompetenssiksi tunnistettiin kuitenkin kollaboratiivinen julkinen johtaminen. Kollaboraation käsitettä kuvattiin monitulkintaiseksi. Artikkelissa se määritellään sisäiseksi tai ulkoiseksi vuorovaikutukseksi, jossa millään taholla ei ole ylivaltaa toisiinsa nähden, vaan neuvottelu, luottamuksen rakentamisen lujittaminen sekä konsensuksen luominen kuvaavat johtajuuden piirteitä $(2017,9)$.

Parkkinen ym. (2017) puolestaan tarkastelevat kuntajohtajien osaamistarpeiden muutoksia. Kuntajohtajien kompetenssit muodostuvat heidän mukaansa kuntajohtajien henkilökohtaisista ominaisuuksista, johtamistaidoista, substanssitaidoista sekä yleisestä osaamisesta, kuten ihmissuhde- ja viestintätaidoista $(2017,29-48)$. Parkkinen ym. ovat tunnistaneet myös niitä ilmiöitä, jotka vaikuttavat kuntajohtajien osaamistarpeisiin. Tällaisiksi ilmiöiksi on nostettu yleinen yhteiskunnallinen muutos, hallinnon uudistukset, kunnan ominaisuudet, poliittinen rajapinta ja tietotekninen kehitys (2017, 49-68).

Virtanen ja Tammeaid (2020) tunnistavat julkisen sektorin johtamisen kapasiteeteiksi oppimaan oppimisen ja oppimiskulttuurin luomisen, julkisten sektorin systeemitason ymmärtämisen ja systeemiin kiinnittyvän johtamisen, yhteis- kuntaan, sidosryhmiin ja asiakkaisiin kiinnittyvän dialogisen toiminta- ja ajattelutavan, ajattelutaitojen kehittämisen sekä mahdollistavien ajattelurakenteiden ja käytännön toimintavalmiuksien luomisen (95-115).

Julkisen hallinnon toimintaympäristön muutoksia ja siitä johtuvia kompetenssitarpeita peilaavat kotimaisessa tarkastelussa myös esimerkiksi Yli-Viikari ja Pasanen (2018). He tarkastelevat siiloutuneen hallinnon haasteita kestävän kehityksen johtamisen näkökulmasta. Digitalisaatio nähdään hallinnonrajoja ylittävien toimintamallien mahdollistajana. Kirjoittajien mukaan hallintokulttuuri on murroksessa ja tarvitaan esimerkiksi verkostomaista valmistelua. Haastavat toimintaympäristön muutokset edellyttävät uudenlaista johtamista. Verkostoissa toimimisen lisäksi muutoksessa tarvitaan ratkaisukeskeisyyttä, tietojohtamista ja kykyä ymmärtää kokonaisuuksia ja organisoida rakenteita (2018, 21).

Tehokkuuden rinnalla kotimaisissa artikkeleissa viitataan myös eettisyyteen. Aiemmassa tarkastelussa eettisyys on liitetty erityisesti korruption torjuntaan ja tuottavuuteen; verorahojen käyttäminen tehokkaasti on eettistä (Lähdesmäki 2011, 79-80). Viime vuosien tutkimuksessa eettisyys kytkeytyy selkeämmin tunneälyyn ja inhimillisyyteen. Yli-Viikari ja Pasanen (2018, 21) tuovat esille esimerkiksi tarpeen johtaa henkilöstöä inhimillisesti. Ranta ym. $(2017,14)$ korostavat, että muutoksissa tarvitaan tunneälyä ja empatiaa. Eettisyyden sisältö on saanut viime vuosina uusia ulottuvuuksia myös tekoälyyn liittyvistä keskusteluista ja hallinnon digitalisaatio on laajemminkin nostanut tuottavuuden rinnalle asiakaslähtöisyyden tarkastelun (Koivisto ym. 2019).

Tunnistamme edellä esitettyjen kansainvälisten ja kansallisten kompetenssiluokitteluiden pohjalta seuraavat kompetenssiryhmät. Ryhmittely ei ole tarkkarajainen, vaan eri ryhmiin sisältyvät kompetenssit ovat limittäisiä ja päällekkäisiä.

Ensimmäisessä ryhmässä on kyse yksilön ominaisuuksiin ja osaamiseen kohdistuvista kompetensseista. Toinen ja kolmas ryhmä kiinnittyvät keskeiseen kollaboraatioon käsitteeseen. Julkisen hallinnon tarkastelun tietoinen laajentaminen instituutioista niitä ympäröivän yhteisön kehitykseen vahvistaa julkisen hallinnon ja 
hallinnan systeemien avoimuutta erilaisten ilmiöiden aiheuttamille muutostarpeille ja lopulta muutosten menestykselle (Bezes 2020). Toisessa ryhmässä kollaboraatiota tarkastellaan organisaation sisäisessä toiminnassa ja kolmannessa ryhmässä suhteessa organisaation ulkopuoliseen toimintaympäristöön. Alla oleva kuvio kokoaa yhteen kansainvälisestä ja kansallisesta kirjallisuudesta esiin nousseet kompetenssit. Eettisyys näyttäytyy erityisenä kompetenssina näissä kaikissa ryhmissä.

\section{TUTKIMUSMENETELMÄT JA AINEISTON KUVAUS}

Tutkimuksemme tieteenfilosofinen orientaatio on pragmaattinen ja osallistava (O'Cathain 2009; Sormunen ym. 2013). Käytimme osallistavia menetelmiä suurimmassa osassa tutkimusaineistoamme (osaamistarvekysely, vuorovaikutteinen työpaja ja asiantuntija Delfoi). Noudatimme tutkimuksessa Tutkimuseettisen neuvottelukunnan (TENK) ohjeita hyvästä tieteellisestä käytännöstä. Tutkimukseen osallistuminen on ollut vapaaehtoista, eikä mihinkään kysymykseen vastaaminen ole ollut pakollista. Tutkimuk- seen osallistuneita ei voida yksityiskohtaisesti tunnistaa.

Luonnehdimme tutkimusmetodologisia valintojamme triangulaation ja monitahoarvioinnin avulla. Triangulaation, eli erilaisten tutkimusmenetelmien ja tietolähteiden monilähtöisyys lisää tutkimuksen luotettavuutta (Tuomi \& Sarajärvi 2002, 141-142). Koimme, että tutkimuksessa julkishallinnon kompetenssien monitulkintaisuus edellytti monitahoarviointina (multiple constituency model). Monitahoarvioinnissa toimintaa tarkastellaan siihen intressejä omaavien tahojen tai avainryhmien perspektiivistä, mihin myös menetelmän constituency -termi viittaa (Vartiainen 1994, 97-99). Avainryhmien ja tutkittavan toiminnan suhdetta voidaan kuvata vastavuoroisena: avainryhmät tarjoavat resursseja toiminnalle ja ovat toisaalta riippuvaisia toiminnan suorituskyvystä.

Seuraava taulukko esittelee tutkimuksen empiiristä aineistoa $(\mathrm{N}=217)$ ja sille asetettuja tavoitteita (taulukko 1). Aineistonkeruuta jäsensi koulutuksen kehittämisnäkökulma. Keräsimme tutkimuksen empiiristä aineistoa vaiheittain käyttäen neljää erilaista menetelmää.

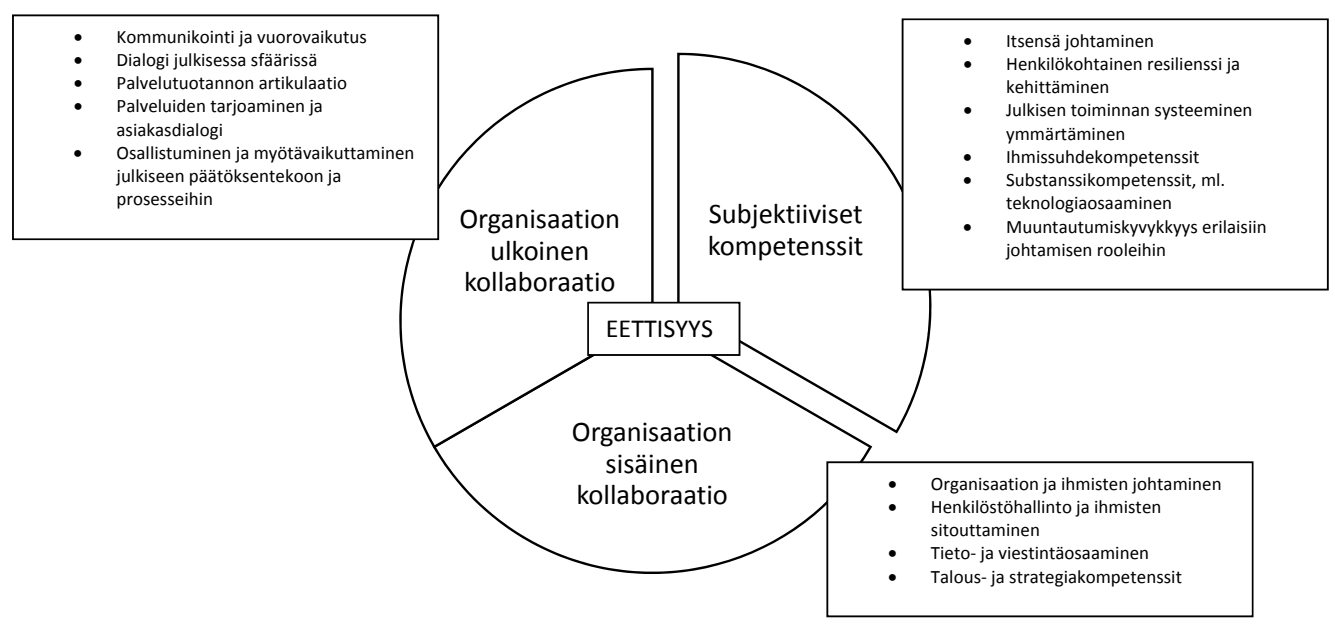

Kuvio 1. Kansainvälisen ja kansallisen kirjallisuuden kompetenssiryhmät. 
Taulukko 1. Tutkimuksen empiirinen aineisto ja sille asetetut tavoitteet.

\begin{tabular}{|c|c|}
\hline Aineiston kuvaus & Tavoite \\
\hline $\begin{array}{c}\text { Ennakointiaineisto } \\
(\mathrm{N}=52)\end{array}$ & $\begin{array}{c}\text { Julkishallinnon koulutuksen osaamistarpeiden } \\
\text { selvittäminen alueellisesta ja kansallisesta } \\
\text { ennakointiaineistosta }\end{array}$ \\
\hline $\begin{array}{c}\text { Osaamistarvekysely } \\
(\mathrm{N}=143)\end{array}$ & $\begin{array}{c}\text { Julkisen hallinnon toimijoiden näkemyksen } \\
\text { selvittäminen ennakointiaineistosta hahmotetuista } \\
\text { osaamiskokonaisuuksista }\end{array}$ \\
\hline $\begin{array}{c}\text { Vuorovaikutteinen työpaja } \\
(\mathrm{N}=10)\end{array}$ & $\begin{array}{c}\text { Osaamistarpeiden syventäminen julkisen hallinnon } \\
\text { toimijoiden ja yliopiston edustajien } \\
\text { vuorovaikutustilanteessa }\end{array}$ \\
\hline Asiantuntija Delfoi & Julkisen hallinnon kehitystrendien ja niihin liittyvien \\
$(\mathrm{N}=12)$ & koulutustarpeiden tarkastelu \\
\hline
\end{tabular}

Alla oleva matriisi (taulukko 2) kuvaa empiirisissä aineistoissa edustettuina olleet avainryhmät jaoteltuna taulukossa 1 kuvatun tutkimusmenetelmän sekä niiden organisaatiotyyppien ja hallinnon tasojen mukaan, joista keräsimme aineistoa. Aineistossa edustettuina olleet organisaatiotyypit ovat julkisen sektorin organisaatiot, yksityiset organisaatiot, voittoa tavoittelemattomat yhdistykset ja säätiöt. Lisäksi tutkimuksessa on tunnistettu organisaatiotyypiksi eräänlaiset hybridiorganisaatiot, jotka omaavat edellisten organisaatiotyyppien piirteitä. Matriisissa esittelemme aineiston jäsentymistä paikalliselle, alueelliselle ja kansalliselle tasolle.

Taulukko 2. Tutkimusempirian matriisi. Edustettuina olleet organisaatiot jaoteltuna tutkimusmenetelmän, organisaatiotyyppien ja hallinnon maantieteellisten tasojen mukaan.

\begin{tabular}{|c|c|c|c|}
\hline & Paikallinen $(\mathrm{N}=105)$ & Alueellinen $(\mathrm{N}=46)$ & Kansallinen $(\mathrm{N}=66)$ \\
\hline $\begin{array}{c}\text { julkisen sektorin } \\
\text { organisaatiot }\end{array}$ & $\begin{array}{l}\text { 1. Kuntaliitto (2) } \\
\text { 2. Kaupunginhallinto (17); } \\
\text { sivistystoimi (9); sote-hallinto } \\
\text { (5); } \\
\text { tekniikka/ympäristöhallinto } \\
\text { (5); kulttuuri ja vapaa- } \\
\text { ajanhallinto (2); Kuntahallinto } \\
\text { (28); sivistystoimi (13); sote- } \\
\text { hallinto (5); } \\
\text { tekniikka/ympäristöhallinto } \\
\text { (8); kulttuuri- ja vapaa- } \\
\text { ajanhallinto (2) } \\
\text { 3. Kuntahallinto (3) } \\
\text { 4. Kaupungin hallinto (2); sote- } \\
\text { hallinto; Kuntahallinto }\end{array}$ & $\begin{array}{l}\text { 1. Maakuntien liitto (18) } \\
\text { 2. TE-toimisto (3); } \\
\text { maanmittauslaitos; } \\
\text { aluehallintovirasto (5); } \\
\text { ELY-keskus (8) } \\
\text { 3. Maistraatti; } \\
\text { Maakuntaliitto; } \\
\text { Kuntayhtymä (sote) } \\
\text { Aluehallintovirasto; } \\
\text { ELY-keskus } \\
\text { 4. ELY-keskus }\end{array}$ & $\begin{array}{l}\text { 1.Opetushallitus (10); } \\
\text { Valtioneuvoston } \\
\text { kanslia/kansallinen } \\
\text { ennakointiverkosto (15) } \\
\text { 2. OM (2); TEM; Tukes; } \\
\text { Huoltovarmuuskeskus; } \\
\text { Tilastokeskus (2); Suomen } \\
\text { Pankki (2); Patentti- ja } \\
\text { rekisterihallitus (2); } \\
\text { Museovirasto (2); } \\
\text { Väylävirasto; Migri (3); } \\
\text { Poliisihallitus; VTV; OPH; } \\
\text { Säteilyturvakeskus; } \\
\text { Valtakunnan syyttäjänvirasto; } \\
\text { UM; Valvira; KELA } \\
\text { 3. Verotoimisto }\end{array}$ \\
\hline $\begin{array}{c}\text { yksityiset } \\
\text { organisaatiot }\end{array}$ & & & $\begin{array}{l}\text { 1. yksityinen ajatushautomo ( } 2) \\
\text { 4. yritysjohtamisen } \\
\text { konsulttitoimisto }\end{array}$ \\
\hline $\begin{array}{c}\text { voittoa } \\
\text { tavoittelemattomat } \\
\text { yhdistykset/säätiöt, } \\
\text { hybridit }\end{array}$ & $\begin{array}{l}\text { 4. Muova; } \\
\text { Nuorisotutkimusverkosto }\end{array}$ & $\begin{array}{l}\text { 2. Kansalaisopisto; } \\
\text { Hyvinvointi- } \\
\text { liikelaitos; kuntien } \\
\text { omistama } \\
\text { jätehuoltoyhtiö } \\
\text { 4. Korkeakouluyhdistys; } \\
\text { Maakunnan liitto }\end{array}$ & $\begin{array}{l}\text { 1. Sitra (5) } \\
\text { 2. ARA; yliopisto (3) } \\
\text { 3. Avoin yliopisto } \\
\text { 4. Kesäyliopisto; KELA }\end{array}$ \\
\hline
\end{tabular}

Tutkimusaineistoissa edustetut organisaatiot $(\mathrm{N}>1)$.

Tutkimusmenetelmät: 1. Ennakointiaineistot $(N=52) ; 2$. Osaamistarvekysely $(N=143) ; 3$. Vuorovaikutteinen työpaja $(N=10) ; 4$. Delfoi-asiantuntijapaneeli $(\mathrm{N}=12)$. 
Artikkelin neljä empiiristä aineistoa täydentävät toisiaan. Ennakointiaineistoista on nähtävissä laajasti eri tyyppisten toimijoiden näkemyksiä aiheesta, sillä aineistoja ovat tuottaneet julkiset, yksityiset ja voittoa tavoittelemattomat toimijat. Aiemmassa kansallisessa kompetenssitutkimuksessa on keskitytty julkisen hallinnon johtajien kompetensseihin. Tavoitteenamme oli selvittää laajemmin julkisessa hallinnossa työskentelevien osaamistarpeita. Osaamistarvekyselyn suuntasimme julkisen hallinnon toimijoille ja kysely kohdennettiin eri rooleissa työskenteleville henkilöille. Myös vuorovaikutteiseen työpajaan ja Delfoi-asiantuntijapaneeliin osallistui johtajien ohella muita toimihenkilöitä sekä asiantuntijoita.

Ennakointiaineistoja tuotetaan kansainvälisellä, kansallisella, alueellisella ja paikallisella tasolla. Osa aineistosta on raportteja tai selvityksiä taikka yhteenvetoja työelämää ja koulutustarpeita koskevista tutkimuksista. Osa julkaisuista taas tarjoaa tulevaisuudentutkimuksellisia visioita siitä, mihin suuntaan yhteiskunta on muuttumassa ja millaiset ilmiöt ovat nousussa. Rajasimme tutkimuksemme aineiston suuren määrän vuoksi kansallisiin ja alueellisiin aineistoihin. Keskityimme ennakointiaineistoissa 2018-2019 julkaistuihin aineistoihin. Alueelliset aineistot koostuivat maakuntaohjelmista ja erilaisista strategiavisioista. Kansallisten tason aineistoja tuottavat hyvin erilaiset toimijat. Sitra on keskeinen kansallisten ennakointiaineistojen tuottaja, ja tutkimus tarkastelee eräitä Sitran aineistoja, kuten Tulevaisuusbarometriä (2019). Laajimman ennakointiaineiston muodostivat Valtionneuvoston kanslian ja Opetushallituksen tuottamat ennakointiaineistot.

Laadultaan aineistot olivat laajoja tekstiaineistoja. Arvioimme ennakointiaineistoja kuvailevan kirjallisuuskatsauksen tavoin siten, että aineistosta on hahmotettu temaattisia kokonaisuuksia (Eskola \& Suoranta 1998, 174-180). Ennakkoaineistoista välittyi kuva eräänlaisina trendi- ja visiolistauksina. Lisäksi ennakointiaineistot olivat moninaisuudestaan huolimatta siinä mielessä yksiäänisiä, että niistä voitiin muodostaa temaattisia kokonaisuuksia.

Osaamistarvekysely laadittiin ennakointiaineistoista esille nousseiden temaattisten kokonaisuuksien pohjalta. Osaamistarvekyselyn tavoitteena oli selvittää, millaisia tiedollisia ja tai- dollisia osaamistarpeita julkisen hallinnon toimijat näkivät tulevaisuudessa tarvittavan. Koska tavoitteenamme oli selvittää erityisesti substanssiosaamiseen liittyviä kompetensseja, työstimme temaattiset kokonaisuudet osaamiskokonaisuuksiksi. Nimesimme osaamiskokonaisuudet seuraavasti: 1) hyvinvointi ja väestörakenteen muutos, 2) muuttuva työ, 3) julkisten varojen käyttö ja 4) hallinnon muutos. Nostimme ennakointiaineistosta nousseiden kokonaisuuksien rinnalle myös kaksi muuta osaamiskokonaisuutta: hyvä valvonta ja sivistykselliset oikeudet hallinnossa. Nostimme nämä kaksi suppeaa osaamiskokonaisuutta kyselyssä esille, koska eräissä julkishallinnon koulutusta tarjoavissa yksiköissä oli noussut esille näihin teemoihin liittyvää koulutuskysyntää.

Suuntasimme kyselyn laajasti valtionhallinnon eri viranomaisille, ammattiliittoihin ja keskusjärjestöihin, itsenäisille julkisoikeudellisille laitoksille (kansaneläkelaitos, Suomen pankki, yliopistot), eräille yksityisille palveluntuottajille sekä kaikille kunnille. Kysely lähetettiin 1500 henkilölle ja vastauksia saatiin 143 . Vaikka vastausaktiivisuus jäi melko alhaiseksi, vastauksia saatiin maantieteellisesti kattavasti ja laajalti eri organisaatioista. Valtaosa vastaajista $(96 / 143)$ työskentelee kuntasektorilla.

Kyselylomake koostui kahdesta osiosta: avoimista kysymyksistä sekä väittämistä. Jälkimmäisissä vastaajien tuli arvioida myönteistä tai kielteistä suhtautumistaan esitettyyn väittämään viisiportaisella Likert-asteikolla. Vastaukset muunnettiin numeerisiksi ja ryhmiteltiin vastaajien asenteiden selvittämiseksi. Avoimet vastaukset puolestaan mahdollistivat sellaisten osaamistarpeiden esiin nostamisen, jotka eivät sisältyneet väittämiin.

Vuorovaikutteisen julkisen hallinnon ja ItäSuomen yliopiston oikeustieteiden laitoksen työpajan tarkoituksena oli syventää ja jäsentää niitä osaamistarpeita, jotka hahmottuivat osaamistarvekyselyn vastauksista. Työpajaan osallistui kymmenen henkilöä Pohjois-Karjalan alueen keskeisimmistä julkisen sektorin organisaatioista. Työpajaan osallistui sekä julkisen hallinnon johtajia että työntekijöitä. Työpajassa keskusteltiin osaamistarpeista osallistujien ymmärryksen, tietojen, havaintojen, kokemusten ja odotusten pohjalta. Väljästi strukturoidussa keskustelussa käsiteltiin ennakointiaineistojen ja osaamistar- 
vekyselyn perusteella hahmotettuja temaattisia osaamiskokonaisuuksia, ajankohtaisia osaamistarpeita, koulutuksen järjestämismuotoja sekä yhteistyömahdollisuuksia. Työpajan jälkeen teemoittelimme keskusteluaineiston.

Asiantuntijapaneelin alustana käytimme eDelphi verkko-ohjelmistoa, jossa asiantuntijat antoivat määrällisen arvionsa julkisen hallinnon tehtävien tulevaisuuteen liittyviin väitteisiin ja perustelivat antamiaan arvioita. Aineistoa analysoitiin sisällönanalyysin menetelmin. Alun perin avaruusteknologian käyttöön kehitetty tutkimusmenetelmä kokoaa yhteen ryhmän asiantuntijoita, jotka arvioivat annettujen tulevaisuusväitteiden todennäköisyyttä ja toivottavuutta, sekä käyvät keskustelua antamistaan arvioista. Yksi menetelmän ominaispiirteistä on vastaajien anonymiteetti, jolla mahdollistetaan asiantuntijoiden välisen keskustelun ilman aseman tai taustaorganisaation mukanaan tuomaa auktoriteettia. Yhteiskuntatieteellisessä kontekstissa Delfoi-metodin käytettävyys korostuu aloilla, joiden kehittämistä edesauttaa niiden tulevaisuuteen suuntautuva, asiantuntijalähtöinen tarkastelu. (Kuusi 2002, 205-207; 2013; Linturi 2007; Landeta 2006.) Metodi mahdollisti lähtökohtaisesti erilaisen tiedon saamisen kuin työpajatyöskentely, jossa korostui vastaajan asema ja organisatorinen tausta.

Toteutimme asiantuntijapaneelin viikon ajanjaksolla, jonka aikana asiantuntijoilla oli mahdollisuus kirjautua ohjelmistoon, tarkastella muiden asiantuntijoiden arvioita ja perusteluja sekä osallistua annetuista väitteistä käytävään keskusteluun. Muodostimme asiantuntijoille annetut, vuoden 2040 julkiseen hallintoon sijoittuvat väitteet tuoreimmasta yhteiskuntatieteellisen korkeakoulutuksen arviointiraportista (Seppälä 2020 ym.) ilmenneiden koulutuksen kehittämistarpeiden mukaisesti. Siten asiantuntijapaneelissa edellä esitetystä aineistosta nousseet havainnot yhdistyivät aiempaan tietoon koulutusalasta. Paneelin näkökulma kiinnittyi erityisesti täydennyskoulutuksen kehittämiseen, mutta väitteiden avulla voitiin arvioida laajemmin julkishallinnon korkeakoulutuksessa tarvittavia kompetensseja. Asiantuntijoita kutsuttiin mukaan 37, joista 12 osallistui aktiivisesti arviointiin ja niistä käytyihin keskusteluihin.

\section{AINEISTOSTA NOUSEVAT JULKISEN HALLINNON OSAAMISTARPEET}

\section{Ennakointiaineistoista saatu tieto julkisen hallinnon osaamistarpeista}

Kansainvälisessä ja kansallisessa kompetensseihin liittyvässä kirjallisuudessa on tunnistettu kompetenssien taustalla erilaisia viitekehyksiä. Tutkimuksissa kompetenssit ovat tyypillisesti melko yleisellä tasolla, eikä kompetensseja ole sidottu viitekehyksistä nouseviin substanssivaateisiin. Pyrimme artikkelissa kompetenssien hienojakoisempaan erittelyyn. Ennakkokäsityksemme on, että tämä edellyttää aluksi niiden taustalla olevien viitekehysten systemaattista analysointia. Tarkastelimmekin erilaisia ennakointiaineistoja ja tunnistimme neljä temaattista kokonaisuutta.

Ensimmäinen ennakointiaineistosta nouseva julkishallinnon koulutuksen kehittämiseen liittyvä temaattinen kokonaisuus on digitalisaatio ja teknologian muutos. Aineistossa esiintyy useita erilaisia teknologioihin, digitalisaatioon ja tekoälyyn liittyviä visioita, haasteita ja hyödyntämisalueita, kuten big datan käyttäminen suunnittelun ja päätöksenteon tukena. Digitalisaation ja teknologian kehityksen nähdään tarjoavan mahdollisuuksia dynaamisempiin prosesseihin ja suuntaavan uudella tavoin hallinnollisia resursseja.

Toinen temaattinen kokonaisuus on julkisen hallinnon organisaatiorakenteiden sekä toimintakulttuurin muutos. Erilaisten rakenteellisten muutosten myötä julkiset palvelut ja julkinen hallinto nähdään alueellisesti ja kansallisesti supistuvana alana. Toisaalta hallinnollista osaamista ennakoidaan tarvittavan esimerkiksi liikeelämän palveluissa, rahoitus- ja vakuutustoiminnassa, koulutuksessa ja tutkimuksessa, järjestötoiminnassa, kaupassa sekä sosiaali- ja terveyspalveluissa. Aineistossa nousee myös esille julkisen hallinnon erilaistuvat toimintamuodot. Tämä ilmentää julkisten ja yksityisten toimintamuotojen lähentymistä. Ennakkoaineistoissa tuodaan esille, että julkinen sektori on muuttumassa sääntelijästä ja peruspalvelujen tuottajasta yksityisen sektorin toimijoiden yhteistyökumppaniksi ja markkinoiden kehittäjäksi. 
Julkisen hallinnon toimintaympäristön muutos asettaa vaatimuksia julkiselle toiminnalle. Aineistosta ilmenee, että hallinnonalakohtaisista toiminnoista ollaan siirtymässä kohti ilmiöpohjaista, yhteiskunnallisten ja globaalien ongelmien yhteisölliseen ratkaisemiseen pyrkivää toimintaa. Julkisen hallinnon toimintakulttuurin muutoksen liittyy myös kansalaisten osallisuuden lisääminen ja varmistaminen erilaisissa vaikutus- ja päätöksentekofoorumeissa.

Kolmas temaattinen kokonaisuus on työnmuutos. Ennakointiaineistossa kuvataan useita erilaisia irrallisia, limittäisiä ja päällekkäisiä työnmuutokseen ilmiöitä. Tällaisia ilmiöitä ovat esimerkiksi perinteisessä työntekijä-työnantajaasetelmassa tapahtuva murros, erilaistuvat työsuhteet tai itsensä työllistämisen muodot. Aineistosta nousee esille konkreettinen yksilötaso, kuten se, miten yksilöiden sosiaalinen yhdenvertaisuus, tai sukupuolten tasa-arvo taataan erilaistuvien työsuhteiden maailmassa. Työnmuutoksella nähdään olevan paikallisia, alueellisia, kansallisia ja globaaleja vaikutuksia. Esimerkiksi perinteisen tuotantotyön väheneminen ja uudenlaisen kansainvälisillä alustoilla toteutettavan työn syntyminen vaikuttaa verotuksen kohdentamiseen ja toteuttamiseen sekä verotulojen kohdentumiseen.

Neljäs temaattinen kokonaisuus liittyy demografiseen muutokseen ja erilaisten väestöryhmien asemaan. Väestörakenteeseen liittyvät seikat ovat esillä suuressa osassa aineistoja, ja nämä kytkeytyvät edellä mainittuihin temaattisiin kokonaisuuksiin. Aineistossa on tunnistettu useita erilaisia ryhmiä ja näiden ryhmien tarpeita. Erityisenä kysymyksenä näyttäytyy väestön ikääntyminen sekä maahanmuuttajien asema ja määrä. Riskinä tuodaan esille sosiaalisen eriarvoisuuden lisääntyminen ja siihen liittyvät syrjäytymisriskit.

\section{OSAAMISTARVEKYSELY}

Osaamistarvekyselyn perusteella keskeisimmäksi julkishallinnon osaamistarpeeksi näyttäytyivät julkisten varojen käyttöön ja hallinnon muutokseen liittyvät kompetenssit. Myös työn muutokseen liittyvät osaamistarpeet nähtiin keskeisiksi. Julkisen hallinnon toimijat eivät nähneet muita osaamiskokonaisuuksia yhtä merkityksellisiksi. Kyselyn taustamuuttujilla ei ollut olennaista vai- kutusta siihen, miten tärkeinä eri osaamiskokonaisuuksia pidettiin. Esimerkiksi julkisten varojen käyttöön liittyvä osaamiskokonaisuus nähtiin tärkeäksi kaikilla kuntien eri toimialoilla ja hyvin erityyppisissä viranomaisissa, kuten väylävirastossa, Huoltovarmuuskeskuksessa, Säteilyturvakeskuksessa ja Suomen pankissa. Sen sijaan näkemykset osaamistarpeiltaan vähemmän merkitykselliseksi koetuista osaamiskokonaisuuksista vaihtelivat. Saman tyyppiset toimijat saattoivat nähdä kokonaisuuksien tarpeellisuuden toisistaan poikkeavalla tavalla. Esimerkiksi kulttuurin ja sivistyksen toimialalla työskentelevistä vastaajista vain osa koki sivistykselliset oikeudet -osaamiskokonaisuuden tarpeellisena.

Julkisen hallinnon toimijat esittivät osaamiskokonaisuuksien arvioinnin ohella näkemyksiään myös muista osaamistarpeista. Vaikka vastauksissa oli hajontaa, oli vastauksista hahmotettavissa tiettyjä teemoja, kuten hyvä ja tehokas hallinto, lainsäädännön ja eri oikeudenalojen tuntemus, yhteistyö- ja viestintäosaaminen, tiedonhallinta ja tietojohtaminen sekä alakohtainen erityisosaaminen.

\section{VUOROVAIKUTTEINEN TYÖPAJA}

Julkisen hallinnon toimijoiden sekä Itä-Suomen yliopiston oikeustieteiden laitoksen vuorovaikutteisessa työpajassa keskusteltiin ennakointiaineiston ja osaamistarvekyselyn perusteella hahmotetuista osaamiskokonaisuuksista. Koska ItäSuomen yliopiston oikeustieteiden yksikkö järjestää ainoastaan oikeustieteellistä koulutusta, painottui työpajassa oikeudelliset osaamistarpeet.

Työpajassa käydyssä keskustelussa korostui erityisesti ilmiöpohjaisuus. Osallistujat kokivat olennaiseksi tarkastella ilmiöitä, kuten ilmastonmuutosta, kokonaisvaltaisesti eri näkökulmista. Keskustelussa kävi ilmi, että monet teemat olivat ajankohtaisia eri organisaatioiden toimijoille. Työpajassa käydyssä keskustelussa nousi erityisenä ajankohtaisena teemana esille valvonta. Valvonnan suunnittelu, dokumentaatio ja hyvä tiedonhallinta sekä tietosuojaan liittyvät asiat tunnistettiin yhteisiksi kaikille valvontaa suorittaville organisaatioille valvonnan kohteesta riippumatta.

Työpajan osallistujat nimesivät yleisiä työelämävalmiuksia. Tällaisiksi tunnistettiin riittävä 
kielitaito, hyvä kirjoitustaito ja kyky tiivistää tekstistä olennaisimmat asiat. Myös yritystoimintaan liittyvää osaamista sekä toimintaympäristön ja organisaatioiden tuntemista pidettiin tärkeänä. Työpajassa nousi esille yhteistyöhön ja vuorovaikutukseen liittyviä osaamistarpeita, sillä osallistujat painottivat viranomaisten yhteistyötä. Keskustelu kiinnittyi tältä osin niihin ilmiöihin ja asioihin, joita eri toimijat käsittelevät omilla toimintakentillään. Esille nousi sopeutuminen muuttuviin tilanteisiin ja muutosten ymmärtäminen sekä avoin keskustelu ja eri toimijoiden välinen yhteistyö.

Muut keskustelussa esiinnousseet osaamistarpeet liittyivät esimerkiksi kilpailu- ja kuluttajansuoja-asioihin, julkisuus- ja tietosuoja-asioihin sekä ulkomaalaiskysymyksiin. Substanssiosaamistarpeita tunnistettiin myös prosessi- ja sopimusoikeudellisissa kysymyksissä sekä julkisissa hankinnoissa.

\section{DELFOI-ASIANTUNTIJAPANEELI}

Delfoi-asiantuntijapaneelissa vastaajat pitivät joko tärkeinä tai erittäin tärkeinä ongelmanratkaisu- ja analyysitaitoja, kykyä uuden oppimiseen, yhteistyö- ja ryhmätyöskentelytaitoja, esiintymis- ja vuorovaikutustaitoja, itsetuntemusta, itsensä johtamista ja itseohjautuvuutta sekä johtamis- ja esimiesvalmiuksia. Vastauksista nousee esille kaksi edellisiä empiirisiä aineistoja tukevaa tulosta. Työnmurros ja väestörakenteen muutos värittävät julkista hallintoa ja vaikuttavat vaadittaviin kompetensseihin. Julkisella sektorilla on ennakoitava muutoksia ja kyettävä vastaamaan niihin osaamisen kehittämisellä.

Enemmistö asiantuntijapaneelin vastaajista piti todennäköisenä ja toivottavana näkemystä, jonka mukaan julkisessa hallinnossa työskennellään yhä enemmän organisaatiorajat ylittävissä, eri tarkoituksia palvelevissa ja muuntuvissa verkostoissa. Verkostomaisten rakenteiden taustalla on hallinnon lisääntynyt ilmiölähtöisyys ja nopeasti muuttuva toimintaympäristö. Verkostomaisissa rakenteissa nähtiin myös haasteita ja korostettiin oman alan osaamisen riittävää hallintaa.

Verkostomainen toimintarakenne tuli esille myös asiantuntijapaneelin juridiikan koulutustarpeita kartoittavassa osiossa. Toisaalta verkostomaiset rakenteet voivat merkitä, ettei tarvitse itse olla juridisten kompetenssien erityisasiantuntija. Juridisten kompetenssien taustalla vaikuttavat vahvasti uudet palveluiden tuottamisen mallit. Hankintaosaaminen koettiin kaikissa vastauksissa erittäin tärkeäksi tai tärkeäksi. Yleisemmin muidenkin kuin organisaatiossa toimivien juristien juridisen osaamisen kehittäminen nähtiin tärkeänä. Jos juridinen osaaminen keskittyy organisaation juristeille, ongelmana pidettiin palveluiden kuormittumista. Juridisessa osaamisessa ei kuitenkaan tule olla kysymys vain lain sanamuodon osaamisesta, vaan lain tarkoituksen ja tavoitteiden ymmärtämisestä. Myös yhteiskunnan ja politiikan periaatteita tulee hallita.

Enemmistö vastaajista piti todennäköisinä ja toivottavana väitettä, jonka mukaan vuonna 2030 työyhteisön erilaisten hyvinvoinnin tarpeiden yhteensovittamisessa korostuu johtamisen vastuu. Yksi vastaaja kirjoittaa, että "kehityssuunta näkyy jo nyt työelämässä ja kumpuaa koulusta ja koulutuksesta." Johtamisessa digitaalisuudella ja työhyvinvoinnilla nähdään yhteys: "Digitaalisuuden johtamiseen työhyvinvoinnin näkökulmasta on määriteltävä myös selkeitä linjauksia, suosituksia, verkostomaisen työskentelyn lisäksi yli organisaatiorajojen sovittavia digitapakoodeja." Paneelin juridisia kompetensseja kartoittavassa osiossa digitaalisuus liitettiin myös kyberturvallisuuteen ja siihen liittyviin valmiuksiin. Lisäksi avoimissa vastauksissa nousi esille myös digitalisaation yhteys julkisen hallinnon avoimuuteen ja läpinäkyvyyteen sekä muotoseikkojen korostumiseen päätöksenteossa.

\section{EMPIIRISEN AINEISTON ANALYYSI}

Olemme koostaneet seuraavaan taulukkoon empiiriset aineistot ja niistä nousevat keskeiset teemat.

Yllä olevasta taulukosta ilmenee, että kaikissa empiirisissä aineistoissa esiintyy hyvin saman tyyppisiä teemoja, vaikka tiedontuottajat ja aineistonkeruumenetelmät olivat erilaisia. Tällaisia teemoja ovat digitalisaatio, työn muutos, hallinnon muutos ja ilmiölähtöisyys. Toisaalta määrätyissä aineistoissa painottuu teemat, jotka eivät puolestaan korostu toisissa aineistoissa. Digitalisaatio nousi voimakkaasti esille ennakointiaineistoista ja Delfoi-asiantuntijapaneelissa, mutta osaamistarvekyselyssä julkisen hallinnon toimijat eivät nostaneet digitalisaatiota 
Taulukko 3. Empiirisistä aineistoista esiin nousseet keskeiset teemat.

\begin{tabular}{|c|l|}
\hline Empiirinen aineisto & Aineistosta nousevat keskeiset teemat \\
\hline \multirow{5}{*}{ Ennakointiaineisto } & - Digitalisaatio ja teknologian muutos \\
& - Julkisen hallinnon rakenteellinen ja kulttuurinen muutos \\
& - Julkisten ja yksityisten toimintamuotojen lähentyminen \\
& - Työn muutos \\
& - Väestörakenteen muutos \\
& - Ilmiölähtöisyys \\
\hline \multirow{5}{*}{ Osaamistarvekysely } & - Julkisten varojen käyttö \\
& - Hyvä ja tehokas hallinto \\
& - Hallinnon muutos \\
& - Työn muutos \\
& - Tiedonhankinta ja tietojohtaminen \\
& - Yhteistyö ja viestintä \\
\hline \multirow{5}{*}{ Vuorovaikutteinen työpaja } & - Ilmiölähtöisyys \\
& - Yleisten työelämätaitojen tärkeys \\
& - Oikeudelliset kysymyksenasettelut \\
& - Valvonta \\
& - Julkiset hankinnat \\
& - Yhteistyö eri toimijoiden kanssa \\
\hline \multirow{5}{*}{ Delfoi-asiantuntijapaneeli } & - Digitalisaatio \\
& - Ongelmanratkaisu- ja analyysitaidot \\
& - Johtamisen muutos \\
& - Organisaatiorajat ylittävä yhteistyö ja vuorovaikutus \\
& - Julkiset hankinnat \\
& - Hyvä hallinto \\
& - Työn muutos \\
\hline & \\
\hline
\end{tabular}

keskeiseksi osaamistarpeeksi. Aineistoista nousevia teemoja yhdistää muutos.

Alla oleva taulukko arvioi kompetenssitarpeita ja koulutuksellista ulottuvuutta neljän toimintaympäristön muutoksen kautta, jotka perustuvat taulukko 3:n keskeisiin teemoihin. Empiirisestä aineistosta esiinnousseet teemat eivät olleet yhteismitallisia, joten osa näistä teemoista kohdentuu toimintaympäristön muutoksiin ja osa konkreettisempiin kompetenssitarpeisiin. Kuten toimme esille teoreettisessa osiossa, kompetensseja tarkastelevat teoriat ovat luonteeltaan melko yleisluontoisia. Tarkoituksenamme on korjata puutetta toimintaympäristön muutosten aineistolähtöisyydellä. Jäsennämme toimintaympäristön muutoksia empiirisestä aineistostamme käsin. Olemme hahmottaneet aineistojen teemojen muodostavan neljä kokonaisuutta: teknologinen muutos, hallinnollinen muutos, työn muutos ja demografinen muutos.

Avaamme taulukossa toimintaympäristön muutosten kytköstä julkisen hallinnon käytän- töihin (kompetenssitarve) ja julkishallinnon osaamistarpeisiin (koulutuksellinen ulottuvuus). Tasot ovat välittömässä yhteydessä toisiinsa, sillä toimintaympäristön muutokset vaikuttavat julkisen hallinnon käytäntöön ja kompetensseihin ja aiheuttavat näin ollen uusia osaamistarpeita julkishallinnon koulutuksessa.

Taulukossa esiintyvät toimintaympäristön muutokset ovat yhteydessä toisiinsa. Digitalisaatio ja teknologian muutos edellyttävät uudenlaista osaamista: toisaalta ne mahdollistavat kansalaisten laajemman osallistumisen ja osallistamisen julkisessa päätöksenteossa, mille on syntynyt tarve väestörakenteen muutoksen kautta.

Konkretisoimme taulukossa 4. osaamistarvetta koulutuksen näkökulmasta. Toimintaympäristön muutoksia voi olla haastavaa huomioida koulutuksen osaamistavoitteissa, mutta niiden tunnistaminen on välttämätöntä opetussuunnitelma- kuin opintojaksotasolla. Teoreettisessa viitekehyksessä korostimme eettisyyden vaikutusta kaikissa kompetenssiryhmissä. Tällä on 
Taulukko 4. Aineistosta esiin nousseet toimintaympäristön muutokset, niihin liittyvät tekijät ja julkishallinnon osaamisen tarpeet.

\begin{tabular}{|c|c|c|}
\hline Toimintaympäristön muutos & Kompetenssitarve & Koulutuksellinen ulottuvuus \\
\hline $\begin{array}{c}\text { Teknologinen muutos } \\
\text { Digitalisaatio } \\
\text { Tekoäly } \\
\text { Big data }\end{array}$ & $\begin{array}{l}\text { - Suunnittelu ja päätöksenteon } \\
\text { tuki } \\
\text { - Ongelmatilanteisiin } \\
\text { puuttuminen } \\
\text { - Johtaminen ja päätöksenteko } \\
\text { - Palvelujen digitalisointi }\end{array}$ & $\begin{array}{l}\text { - Datan keräämiseen, } \\
\text { yhdistelemiseen ja } \\
\text { hyödyntämiseen liittyvä } \\
\text { osaaminen } \\
\text { - Kyberturvallisuuteen } \\
\text { kytkeytyvät tiedot ja taidot }\end{array}$ \\
\hline $\begin{array}{l}\text { Hallinnollinen muutos } \\
\text { Organisaatiorakenteiden ja } \\
\text { toimintakulttuurin muutos } \\
\text { Julkisen sektorin roolin muutos }\end{array}$ & $\begin{array}{l}\text { - Ilmiöpohjainen, } \\
\text { yhteiskunnallisten ja globaalien } \\
\text { ongelmien yhteisöllinen } \\
\text { ratkaiseminen } \\
\text { - Kokeilut, esim. } \\
\text { perustulokokeilu } \\
\text { - Julkiset hankinnat }\end{array}$ & $\begin{array}{l}\text { - Hallinnonalarajat ylittävän } \\
\text { yleisosaamisen tarve } \\
\text { - Empiiriset tutkimusmenetelmät } \\
\text { - Vaikutusten arviointi } \\
\text { - Oikeudellis-hallinnollinen } \\
\text { Osaaminen } \\
\text { - Ymmärrys politiikan } \\
\text { ja yhteiskunnan } \\
\text { toimintaperiaatteista }\end{array}$ \\
\hline $\begin{array}{c}\text { Työn muutos } \\
\text { Uudenlaiset työsuhteet, työn } \\
\text { muodot ja työtavat }\end{array}$ & $\begin{array}{l}\text { - Muutos työntekijä-työnantaja- } \\
\text { asetelmassa } \\
\text { - Erilaistuvat työsuhteet } \\
\text { - Työtehtävien katoaminen } \\
\text { - Uudet työtehtävät }\end{array}$ & $\begin{array}{l}\text { - Tasa-arvo työelämässä } \\
\text { - Työntekijän ja työnantajan } \\
\text { oikeudet ja velvollisuudet } \\
\text { - Verotuksen kohdentuminen ja } \\
\text { toteuttaminen } \\
\text { - Johtamisosaaminen } \\
\text { - Työyhteisön hyvinvointi }\end{array}$ \\
\hline $\begin{array}{l}\text { Demografinen muutos } \\
\text { Väestön ikääntyminen } \\
\text { Maahanmuutto } \\
\text { Kaupungistuminen }\end{array}$ & $\begin{array}{l}\text { - Eri sukupolvien } \\
\text { johtamisosaaminen } \\
\text { - Kulttuurien välinen } \\
\text { vuorovaikutusosaaminen } \\
\text { - Eri väestöryhmien } \\
\text { tunnistaminen palveluiden } \\
\text { kehittämisessä }\end{array}$ & $\begin{array}{l}\text { - Yhdenvertaisuuteen liittyvä } \\
\text { osaaminen: hallinnon etiikka ja } \\
\text { juridiikka } \\
\text { - Syrjäytymisen ehkäiseminen } \\
\text { - Kansalaisten osallistaminen } \\
\text { - Kaupunkikehittäminen }\end{array}$ \\
\hline
\end{tabular}

seurauksensa myös koulutukseen sekä tasa-arvon ja hallinnon etiikan kysymyksiin julkishallinnon opettamisessa, johon vaikuttaa usea toimintaympäristön muutostekijä.

\section{Empiirinen aineisto teorian valossa}

Alussa tulkitsimme kansainvälisen ja kansallisen kirjallisuuden perusteella kolme kompetenssikokonaisuutta: organisaation ulkoisen kollaboraation, organisaation sisäisen kollaboraation ja subjektiiviset kompetenssit. Aineiston perusteella tunnistetut teemat eivät rajaudu yksittäisen kompetenssikokonaisuuden sisälle. Esimerkkinä voidaan käyttää työn muutosta. Työn muutos liittyy erilaistuviin työsuhteisiin ja työn muotoihin sekä muutoksiin työntekijän ja työnantajan välillä. Nämä vaativat uusia juridisia kom- petensseja ja erilaista johtamisosaamista. Työn muutos vaikuttaa subjektiivisiin kompetensseihin siten, että johtamistaidoissa korostuu kyky johtaa itseään ja omaksua uuden tilanteen luomia tietoja ja taitoja. Toisaalta työn muutos vaikuttaa organisaation sisäiseen kollaboraatioon; henkilöstöhallintoon ja ihmisten sitouttamiseen. Työn muutos voi tarkoittaa, että aiemmin julkisen hallinnon organisaation sisällä tehtyä työtä toteuttaa nykyisin organisaation ulkopuolinen toimija. Tällöin kompetenssit liittyvät organisaation ulkoiseen kollaboraatioon. Toki työn muutos edellyttää myös yleisiä työelämätaitoja, kuten kirjallista viestintää ja vuorovaikutustaitoja.

Kuten kansainvälisessä ja kansallisessa kirjallisuudessa myös empiirisessä aineistossamme korostuu sekä organisaation sisäinen että ulkoinen kollaboraatio. Kollaboraation merkitys ei 
toisaalta ole mikään uusi ilmiö, mutta aineistojen perusteella yhteistyön merkitys tulee entisestään syvenemään. Moni aineistoissa ilmenevä aihe koskettaa poikkisektoriaalista yhteistyötä ja vuorovaikutusta muun yhteiskunnan kanssa. Poikkisektoriaalinen yhteistyö voi tarkoittaa julkisen ja yksityisen toimijan välisen yhteistyön kompetensseja, kuten julkista hankintaosaamista tai markkinoiden yhteiskehittämistä. Palveluiden osalta palveluiden tuottamisen mallit kehittyvät (esim. monituottajamallit) ja tuovat mukanaan uusia kompetenssitarpeita. Näistä yksi tärkeimpiä on valvontaosaamisen kehittäminen - tämä tuotiin esille useissa aineistoissa.

Toimintaympäristön muutokset korostavat ilmiölähtöisiä kokonaisuuksia, joissa toiminta ei pysy organisaation sisällä, vaan edellyttää sekä organisaation sisäistä että ulkoista kollaboraatiota. Julkiset toimijat eivät voi tarkastella julkisen hallinnon kysymyksiä ainoastaan omista lähtökohdistaan. Ilmiöperustaisuus ja siihen liittyvät haasteet on tuotu esille monilla hallinnon tasoilla: esimerkiksi valtioneuvoston toiminnassa on nähty haasteita juuri monitieteisessä ja monia ongelmia yhdistävässä päätöksenteossa. (Valtioneuvoston oikeuskanslerin kertomus 2017). Toiminen monialaisissa verkostoissa edellyttää oman substanssin hallintaa. Tällöin toimija voi tuoda yhteistyöhön riittävästi sisältöä eikä toiminta jää pinnalliseksi.

Myös digitalisaatio liittyy kaikkiin kolmeen kompetenssiryhmään. Digitalisaatiolla on merkittävä rooli yhteiskunnassa. Digitalisaatiolla esimerkiksi tehostetaan hallintoa yksityistämisen epäonnistuttua tässä tehtävässä monissa maissa (Lethbridge 2019). Eurooppalaisessa digitaalisen osaamisen viitekehyksessä (DigComp) on tunnistettu lukuisia digitaalisia avaintaitoja, jotka jäsentyvät seuraaviin kokonaisuuksiin: digitaalisten sisältöjen lukutaito, kommunikaatio ja kollaboraatio, digitaalisten sisältöjen tuottaminen, turvallisuus ja ongelmanratkaisu (EU 2019). Nämä avaintaidot osoittavat, että digitaalisaatiossa on kyse subjektiivisista kompetensseista; julkisen hallinnon ammattilaisten yleisistä valmiuksista hyödyntää informaatioteknologiaa. Toisaalta julkisen hallinnon digitalisaatio liittyy sekä sisäiseen että ulkoiseen kollaboraatioon.

\section{JOHTOPÄÄTÖKSET JA KESKUSTELU: MITÄ HAVAINTOMME TARKOITTAVAT KOULUTUKSEN KEHITTÄMISEN NÄKÖKULMASTA?}

Koulutuksen näkökulmasta edellä esiin nousseet havainnot voidaan tiivistää kolmeen kokonaisuuteen: muutos ja muuntautumiskyky, verkostoituva julkinen hallinto ja ilmiölähtöisyys sekä kollaboraatio ja asiakaslähtöisyys.

\section{Muutos ja muuntautumiskyky}

Tutkimuksen empiirinen aineisto osoittaa vastaajien tunnistaneen toimintaympäristön keskeiset muutokset. Julkisen hallinnon tehtävissä toimivilta muutos edellyttää muuntautumiskykyisyyttä ja kykyä liikkua eri roolien välillä. Vaikka toimintaympäristön muutokset, kuten verkostomaisissa hallinnon rakenteissa toimiminen, korostuivat aineistossamme, painottuivat käytännön spesifit tarpeet vastaajien näkemyksen mukaan kuitenkin perinteiseen substanssiosaamiseen. Tämä voi johtua siitä, että suurin osa empiirisen osiomme vastaajista oli esimiesja johtotehtävissä ja toiminut työurallaan kauan. Vasta työuransa aloittaneiden näkökulma kompetensseista olisi voinut olla erilainen. Koulutuksen kehittämiseen kiinnittyvät kysymyksenasettelut saattoivat myös omalta osaltaan ohjata vastausten näkökulmaa.

Edellä esitetyn perusteella voimme todeta, että julkisen hallinnon muutos ja sen edellyttämät osaamistarpeet, kuten innovaatio- ja kompleksisuusosaaminen, on syytä ottaa vahvemmin mukaan julkishallinnon koulutuksen kehittämiseen. Luoma ym. (2020) tarkastelivat selvityksessään kompleksisuuden opetuksen tilannetta suomalaisessa korkeakouluopetuksessa, erityisesti johtamista korostavissa ohjelmissa. Selvityksen perusteella kompleksisuuden käsittely jää hallintotieteiden opetuksessa vielä vaatimattomalle tasolle. Jatkuvan oppimisen kokonaisuudet voivat myös tarjota tärkeitä reittejä innovaatio- ja kompleksisuusvalmiuksien kulkeutumiseen käytännön hallintotyöhön.

\section{Hallinnon ilmiölähtöisyys}

Yhteiskunnan monimutkaistuvat ja hallinnon rajoja ylittävät ilmiöt ovat tuoneet kompetenssitarpeisiin uusia ulottuvuuksia. Julkisen hallinnon 
rakenteet kehittyvät yhä verkostomaisemmiksi. Yliopistojen tutkintoasetus (VnA 794/2004) on ohjannut muodostamaan tutkinnot siten, että ne muodostuvat pääaineessa suoritettavista perus- ja aineopinnoista. Koulutusalojen rajoja ylittäviin temaattisiin ja moduulimaisiin koulutuksen toteuttamismalleihin on alettu siirtyä vasta hiljattain. Modulaariset ja temaattiset opintokokonaisuudet vastaavat edellä esitettyihin havaintoihin ilmiöpohjaisesta ja poikkisektoriaalisesta osaamistarpeesta. Tämä ei tarkoita sitä, etteikö oman alan vahvaa substanssiosaamista tarvita jatkossakin.

Ilmiöihin ja sidosryhmäyhteistyöhön liittyy myös syvällisempiä haasteita. Tutkimuksessa tarkasteltu kirjallisuus sekä empiirinen aineisto ovat nostaneet esille joitain sidosryhmäyhteistyöhön liittyviä riskejä ja tästä johtuvia kompetenssitarpeita. Esimerkiksi eurooppalaisessa julkisen hallinnon tutkimuksessa merkittävänä trendinä nähdään tieteiden rajat ylittävä ja erilaiset sidosryhmät huomioiva tutkimus. Hallinto-tieteellinen tutkimus vakiinnuttaa siten asemaa suhteessa yhteiskunnalliseen päätöksentekoon, mutta julkisen hallinnon tarkastelun neutraalius saattaa vaarantua erilaisten poliittisten ilmiöiden, mm. populismin, mukanaan tuoman julkisen keskustelun myötä. (Karré ym. 2020; Stoker 2019.) Nykyhallinnon ydinkompetenssina voidaankin nähdä kyky tunnistaa sidosryhmäyhteistyön riskejä suhteessa julkisen hallinnon neutraalisuuteen, tulevatpa riskit ilmi julkiseen hallintoon soveltavan tutkimuksen kautta tai muunlaisen yhteistyön vanavedessä. Riskien hallinnan välineinä toimivat esimerkiksi eettiset tai juridiset reunaehdot, kuten empiirisessä aineistossamme esille noussut esteellisyys- ja julkisuusnormiston tunteminen.

\section{Kollaboraatio ja asiakaslähtöisyys}

Kollaboraatio näyttäytyy keskeisenä kaikissa tarkastelemissamme empiirisissä aineistoissa sekä kirjallisuudessa. Empiirisen aineistomme perusteella näyttää siltä, että yhteistyötä korostetaan erityisesti organisaation sisällä ja eri sidosryhmien välillä. Tämä ei tarkoita välttämättä asiakasnäkökulmaa ja asiakaslähtöistä kehittämistä, joka tuntuu käytännön työssä typistyvän lähinnä sille minimitasolle, jota asiakkaiden juridiset oikeudet edellyttävät. Vaikka teoreettisella tasol- la asiakasnäkökulmaa on korostunut, voidaan empiirisen aineistomme pohjalta arvioida, että tämä lähtökohta ei ole siirtynyt kovin vahvasti käytäntöön.

Koulutuksen näkökulmasta on mahdollista, että vasta tulevaisuuden julkishallinnon toimijat vievät hallintoon mukanaan tällä hetkellä koulutuksessa painotettavia asiakaslähtöisyyden ja osallisuuden elementtejä. Moni tällä hetkellä julkishallinnossa työskentelevä on saanut pohjakoulutuksensa aikana, jolloin kollaboraatio typistyi konservatiivisempaan ajatukseen organisaation sisäisestä ja sidosryhmien välisestä yhteistyöstä.

Virallisissa dokumenteissa ja kansainvälisessä tutkimuksessa (esim. Sabbagh ym. 2012; Saxena 2005) julkisen hallinnon digitalisaatiokehitykseen liitetään erityisen vahva asiakasnäkökulma. Vaikka esimerkiksi tekoälyn hyödyntämiseen julkisessa hallinnossa kiinnittyy myös tehokkuuden diskurssi, tässä keskustelussa on lähes poikkeuksetta läsnä myös asiakaslähtöisyys ja eettisyyden painotus. Tämä digitalisaation mukanaan tuoma vahva asiakaslähtöisyyden tarve voi osaltaan olla juurruttamassa tätä näkökulmaa syvemmin myös hallintotoimintaan tulevaisuudessa. Näin on varsinkin Suomessa, jossa yhteiskunnan digitalisaatio on Euroopan kehittyneimmällä tasolla, ja siihen kiinnitetään huomiota julkishallinnon koulutuksessa.

\section{LÄHTEET}

Berman, Evan Michael, \& West, Jonathan P. (2008). Managing emotional intelligence in U.S. cities: A study of social skills among public managers. Public Administration Review, 68(4), 742-758. https://doi.org/10.1111/j.1540-6210.2008.00912.x Bertels, Jana, Bouckaert, Geert \& Werner, Jann (2020). The Survey: A Long-Distance Conversation about the Future of Public Administration in Europe. Teoksessa Bouckaert, Geert \& Jann, Werner (Eds.) European Perspectives for Public Administration: The Way Forward (s.43-68). Leuven: Leuven University Press. https://doi.org/10.2307/j.ctvv417th.13

Bezes, Philippe (2020). Seeing public bureaucracies like a sociologist: (A plea towards) reconnecting sociology and public administration. Teoksessa Bouckaert, Geert \& Jann, Werner (Eds.): European Perspectives for Public Administration: The Way Forward (s. 163-188). Leuven: Leuven University Press. https://doi.org/10.2307/j.ctvv417th.13 
Bouckaert, Geert \& Jann, Werner (2020). Lessons and next steps. Teoksessa Bouckaert, Geert \& Jann, Werner (Eds.): European Perspectives for Public Administration: The Way Forward (s. 455-465). Leuven: Leuven University Press. 455-465. https://doi.org/10.2307/j.ctvv417th.28

Brans, Marleen \& Coenen, Laurien (2016). The Europeanization of Public Administration teaching. Policy and Society, 35(4), 333-349. https://doi.org/10.1016/j.polsoc.2016.11.005

Denhardt, Robert B. (2001). The Big Questions of Public Administration Education. Public Administration Review, 61(5), 526-534. https://doi.org/10.1111/0033-3352.00125

Eskola, Jari \& Suoranta, Juha (1998). Johdatus laadulliseen tutkimukseen. Tampere: Vastapaino.

EU (2019). Digital Competence Framework 2.0. Haettu sivulta https://ec.europa.eu/jrc/en/digcomp/digital-competence-framework, 1.12.2020.

Euroopan komissio (2019). The Digital Economy and Society Index (DESI). Haettu sivulta https://ec.europa.eu/digital-single-market/en/ desi, 1.12.2020.

Euroopan komissio (2016). Euroopan komission tiedonanto: EU:n sähköisen hallinnon toimintaohjelma. Hallinnon digitalisaatiokehityksen vauhdittaminen. SWD (2016) 108 final.

Haupt, Brittany, Kapucu, Naim \& Hu, Qian (2017). Core Competencies in Master of Public Administration Programs: Perspectives from Local Government Managers. Journal of Public Affairs Education, 23(1), 611-624. https://doi.org/10.1080/15236803.2017.12002272

International City/County Management Association (ICMA) (2015). Practices for Effective Local Government Management. Haettu sivulta http://icma.org/en/university/about/ management_practices, 15.11.2020.

Karré, Philip, van der Steen, Martijn, van der Wal, Zeger \& Schillemans, Thomas (2020). Public Administration in the Netherlands: State of the Field. Teoksessa Geert Bouckaert \& Werner Jann (Eds.): European Perspectives for Public Administration: The Way Forward (s. 403-420). Leuven: Leuven University Press. https://doi.org/10.2307/j.ctvv417th.25

Koivisto, Raija, Leikas, Jaana, Auvinen, Heidi, Vakkuri, Ville, Saariluoma, Pertti, Hakkarainen Jenni \& Koulu, Riikka (2019). Tekoäly viranomaistoiminnassa - eettiset kysymykset ja yhteiskunnallinen hyväksyttävyys. Valtioneuvoston selvitys- ja tutkimustoiminnan julkaisusarja 14/2019.

Kotiranta, Sami \& Ahonen, Pertti Pellervo (2017). Ylimpien virkamiesten kompetenssi ja johtajuus suhteessa toimintaympäristön asettamiin vaatimuksiin ja tarjoamiin mahdollisuuksiin: systemaattinen katsausanalyysi. Helsinki: Sitra. Haettu sivulta http://media.sitra.fi/2017/10/05133300/ JSJ_Kirjallisuuskatsaus_FINAL_

KotirantaAhonenSitra_31-08-2017-pdf.pdf, 1.12.2020.

Kuusi, Osmo (2002). Delfoi-menetelmä. Teoksessa Kamppinen, Matti, Kuusi, Osmo \& Söderlund, Sari (Toim.): Tulevaisuuden Tutkimus: Perusteet ja Sovellukset (204-225). Helsinki: Suomalaisen Kirjallisuuden Seura.

Landeta, Jon (2006). Current validity of the delphi method in social sciences. Technological Forecasting and Social Change 73(5), 467-482. https://doi.org/10.1016/j.techfore.2005.09.002, 15.11.2020.

Larat, Fabrice (2017). Developing an Integrated and Comprehensive Training Strategy for Public Sector Leaders: The French Experience. Teaching Public Administration, 35(1), 88-104. https://doi.org/10.1177/0144739416655598

Lethbridge, Jane (2019). Democratic professionalism in public services. Bristol: Bristol University Press. https://doi.org/10.2307/j.ctvhktk4b

Linturi, Hannu (2007). Delfoin metamorfooseja. Futura 26(1). Haettu sivulta http://elektra. helsinki.fi/se/f/0785-5494/26/1/delfoinm.pdf, 1.12.2020.

Lokhoff, Jenneke, Wegewijs, Bas, Durkin, Katja, Wagenaar, Robert, González, Julia, Isaacs, Ann Katherine, dalle Rose, Luigi F. Donà \& Gobbi, Mary (2010). A Tuning Guide to Formulating Degree Programme Profiles: Including Programme Competences and Programme Learning Outcomes. Competences in Education and Recognition Project (CoRe). Bilbao: Universidad de Deusto.

Luoma, Mikko, Ahokallio-Leppälä, Heidi \& Vartiainen, Pirkko (2020). Kompleksisuuden opetus suomalaisissa korkeakouluissa. Teoksessa Vartiainen, Pirkko \& Raisio, Harri (Toim.): Johtaminen kompleksisessa maailmassa: viisautta pirullisten ongelmien kohtaamiseen (s. 160-182). Helsinki: Gaudeamus.

Lähdesmäki, Kirsi (2011). New Public Management julkisjohtamisen uudistajana - yhä kestosuosikki reformeissa? Teoksessa Hyyryläinen, Esa \& Viinamäki, Olli-Pekka (Toim.): Julkinen hallinto ja julkinen johtaminen. Acta Wasaensia. 238 julkisjohtaminen 16 (s. 74-87). Vaasa: Vaasan yliopisto.

McQuiston, James M. \& Manoharan, Aroon P. (2017). Developing E-Government Coursework through theNASPAA Competencies Framework. Teaching Public Administration, 35(2), 173-189. https://doi.org/10.1177/0144739417690582 
Network of Schools of Public Policy, Affairs, and Administration (NASPAA) (2014). NASPAA Standards: Accreditation Standards for Master's Degree Programs. Haettu sivulta

https://naspaaaccreditation.files.wordpress. com/2015/02/naspaa-accreditation-standards. pdf, 1.12.2020.

Nyholm, Inga \& Virtanen, Petri (2017. Mitä tiedämme julkishallinnon johtajien osaamistarpeista? Sitra. Haettu sivulta https://www.sitra.fi/artikkelit/mita-tiedamme-julkishallinnon-johtajien-tulevista-osaamistarpeista/, 1.12.2020.

O'Cathain, Alicia (2009). Mixed methods research in the health sciences. A quiet revolution. Journal of Mixed Methods Research, 2009(3), 3-6. https://doi.org/10.1177/1558689808326272

Ongaro,Edoardo(2019). The TeachingofPhilosophy in Public Administration Programmes. Teaching Public Administration, 37(2), 135-146. https://doi.org/10.1177/0144739419837310

Parkkinen, Jonne, Haveri, Arto \& Airaksinen, Jenni (2017). Yhdistävä johtajuus: tutkimus kuntajohtajien osaamistarpeiden muutoksesta. Helsinki: Suomen kuntaliitto.

Parviainen, Päivi, Kääriäinen, Jukka, Honkatukia, Juha \& Federley, Maija (2017). Julkishallinnon digitalisaatio - tuottavuus ja hyötyjen mittaaminen. Valtioneuvoston tutkimus- ja selvitystoiminnan julkaisusarja 3/2017.

Pietiläinen, Ville (2010). Johtajan ammatillisten kompetenssien profiloituminen kompleksisessa toimintaympäristössä: Tapausesimerkkinä opetustoimen alaiset oppilaitosorganisaatiot. Akateeminen väitöskirja. Rovaniemi: Rovaniemen yliopisto.

Raisio, Harri, Puustinen, Alisa \& Vartiainen, Pirkko (2020). Kompleksisuusjohtajuus organisaation adaptiivisuuden mahdollistajana - tutkimuskohteena Opetushallitus. Teoksessa Vartiainen, Pirkko \& Raisio, Harri (Toim.): Johtaminen kompleksisessa maailmassa: viisautta pirullisten ongelmien kohtaamiseen (s. 108-132). Helsinki: Gaudeamus.

Ranta, Tommi, Manu, Samuli, Laasonen, Valtteri, Uusikylä, Petri \& Leskelä, Riikka-Leena (2017). Kohti uusia maakuntia Sote- ja maakuntauudistuksen toimeenpanon esivalmisteluvaiheen yhteenveto. Valtioneuvoston selvitys ja tutkimustoiminnan julkaisusarja 74/2017. Haettu sivulta https://julkaisut.valtioneuvosto.fi/handle/10024/160398, 2.12.2020.

Reichard, Christoph \& van der Krogt, Theo (2014). Towards a set of specific competences for academic degree programmes in Public Administration in Europe. Paper for a working group VIII on public administration education at the 22nd NISPAcee conference in Budapest, 22-24 May
2014. Haettu sivulta https://api.semanticscholar. org/CorpusID:155193685 1.12.2020.

Sabbagh, Karim, Friedrich, Roman, El-Darwiche, Bahjat, Singh, Milind, Ganediwalla, Sandeep, \& Katz, Raul (2012). Maximizing the impact of digitization. The Global Information Technology Report 2012: Living in a Hyperconnected World. 68-73. Haettu sivulta

http://www3.weforum.org/docs/Global_IT_ Report_2012.pdf 1.12.2020.

Saxena (2005). K.B.C. Towards excellence in e-governance. International Journal of Public Sector Management, 18(6), 498-513.

https://doi.org/10.1108/09513550510616733

Seppälä, Ullamaija, Kivistö, Jussi, Joas, Marko, Kaikkonen, Viivi, Rantanen, Teemu, Rantanen, Terhi, Tiilikainen, Teija \& Nordblad, Mirella (2020). Yhteiskuntatieteellisen korkeakoulutuksen arviointi. Kansallisen koulutuksen arviointikeskus. Haettu sivulta https://karvi.fi/app/ uploads/2020/01/KARVI_0220.pdf, 1.12.2020.

Sormunen, Marjorita, Saaranen, Terhi, Tossavainen, Kerttu \& Turunen, Hannele (2013). Monimenetelmätutkimus terveystieteissä. Sosiaalilääketieteellinen aikakauslehti 50, 312-321.

Stoker, Gerry (2019). Can the governance paradigm survive the rise of populism? Policy \& Politics 47(1), 3-18. https://doi.org/10.1332/03 0557318X15333033030897

Virtanen, Petri, \& Tammeaid, Marika (2020). Developing public sector leadership new rationale, best practices and tools. Cham: Springer. https://doi.org/10.1007/978-3-030-42311-7

Tuomi, Jouni \& Sarajärvi, Anneli (2002). Laadullinen tutkimus ja sisällönanalyysi. Helsinki: Tammi.

Valtioneuvoston oikeuskanslerin kertomus (2017). Haettu sivulta https://www.okv.fi/media/filer_public/f3/c4/ f3c47a1a-2e2c-46ce-8c69-2759b4959717/kertomus2017_valmis.pdf, 15.11.2020.

Vartiainen, Pirkko (1994). Palveluorganisaatioiden tuloksellisuusarviointi, teoriat ja käytäntö. Päivähoitoon, erityisesti päiväkoteihin kohdistuva monitahoarviointi. Acta Wasaensia 40. Hallintotiede 2. Vaasa: Vaasan yliopisto.

Wright, Maurice (1974). Teaching Public Administration. Public Administration, 52(1), 73-78. https://doi.org/10.1111/j.1467-9299.1974. tb00166.x

Yli-Viikari, Tytti \& Pasanen Anna-Liisa (2018). Kestävän kehityksen johtaminen yli hallinnon rajojen. Teoksessa Kohti vaikuttavaa päätöksentekoa ja johtamista hyvinvointipalveluissa. Lammintakanen, Johanna \& Laulajainen, Sanna (Toim.). Kuopio: University of Eastern Finland (s.21-30). 